\title{
PLASMA LEUTINIZING HORMONE PROFILING IN NORMAL AND REPEAT BREEDING KANKREJ COW
}

\author{
N. F. CHAUDHARI*, B. N. SUTHAR ${ }^{1}$, SANDHYA S. CHAUDHARI ${ }^{2}$ \\ C. F. CHAUDHARI AND L. C. MODI \\ Department of Veterinary Gynaecology and Obstetrics \\ College of Veterinary Science and Animal Husbandry \\ Navsari Agricultural University, Navsari \\ Gujarat - 396 450, India
}

\begin{abstract}
The present investigation on plasma leutinizing hormone (LH) profile of 12 Kankrej cow (6 normal and 6 repeat breeding) was carried out on the day of estrus. The mean plasma LH concentration at 2 hours intervals from 8 hours to 36 hours post estrus was significantly $(p<0.05)$ higher in control as compared to repeat breeder group at all the period of sampling except during first two collection where nonsignificant higher level was observed. Further, in control group the level of plasma LH was increased from $8 \mathrm{hrs}$. after onset of estrus and reached a peak level at 20 hours $(4.62 \pm 0.52 \mathrm{mIU} / \mathrm{mL})$ and thereafter it declined. Whereas, no such trend was observed in repeat breeder group.
\end{abstract}

Key words: ELISA, Estrus, Kankrej cow, LH, Repeat breeding

Following breeding, fertilization and maintenance of normal pregnancy and its successful termination are the major reproductive traits of economic concern. If these traits not followed normally, results into increased service period associated mainly with repeat breeding due to certain intrinsic and extrinsic ailments. The animals suffered with repeat breeding possesses normal reproductive tract and express regular oestrous cycle but fail to conceive within 2-3 services to a fertile bull or inseminations. This condition has been studied extensively in cattle (Reddy et al., 2001; Sharma et al., 2006). The synchrony between embryo survival and maternal environment is essential to restore normal fertility in repeat breeding animals. Lack or delayed LH surge will result into the anovulation or delayed ovulation which ultimately makes the animal repeat breeder. It can be maintained by correlation of

\footnotetext{
*Corresponding Author

${ }^{1}$ Department of Veterinary Gynaecology \& Obstetrics, College of Veterinary Sci. \& A.H., SDAU, Dantiwada, Gujarat

${ }^{2}$ Department of Veterinary Physiology \& Biochemistry, College of Veterinary Sci. \& A.H., NAU, Navsari, Gujarat
} 
adequate luteal function either by exogenous supplementation of progesterone or stimulations of steroidogenesis by advocating leutinizing hormone. Hence, in the present study, an attempt was made to ascertain the plasma LH profile of randomly selected repeat breeder cows and to compare it with normal fertile animals.

\section{MATERIALS AND METHODS}

The present study was performed as a part of M.V.Sc. research work, which was approved by Director of Research, Sardarkrushinagar Dantiwada Agricultural University, Sardarkrushinagar, Gujarat in the year 2008. For the investigation, total 12 cyclic and apparently healthy female Kankrej cows irrespective of age and parity, comprised of 6 normal fertile (LH CON), which conceived at 1 st or 2 nd breeding and 6 repeat breeder (LH RB) cows maintained at Livestock Research Station, Sardarkrushinagar Dantiwada Agricultural University, Sardarkrushinagar were selected. All the cows were maintained under identical condition of feeding and management at the Livestock Research Station, Sardarkrushinagar Dantiwada Agricultural University, Sardarkrushinagar. The estrus detection was carried out by teaser bull parading two times in a day. The repeat breeder cows were selected on the basis of history of failure to conceive even after 2 or more breeding with fertile semen and having the normal genital tract, healthy discharge and nearly normal estrus cycle length.
The blood was collected aseptically from the jugular vein taking all the aseptic precautions using EDTA vaccutainers after proper restraining of the animals at every 2 hours, starting from 8 hours to 36 hours post estrus in all the cows. The plasma was separated by centrifuging the blood sample at $4500 \mathrm{rpm}$ for 5 minutes and stored at $20^{\circ} \mathrm{C}$ till analyzed. Plasma LH was estimated using ELISA (Enzyme Linked Immuno-Sorbant Assay) by employing standard kit manufactured by Syntron Bioresearch, Inc. California. Sample, standards and marker were added into the antibody (anti LH) coated wells of 96-well flat bottom microplate. The microplate was incubated at $37^{\circ} \mathrm{C}$ for 30 minutes. Then the wells of microplate were washed for five times using triple distilled water followed by addition of tetramethyl benzidine base (TMB) substrate to each well. The plate was then incubated at room temperature (15$28^{\circ} \mathrm{C}$ ) for 10 minutes. Stop solution was added in to each well in dark to check the reaction. The absorbance of these wells was read against blank at $450 \mathrm{~nm}$. The values were calculated against a standard curve of 0 to $200 \mathrm{mIU} / \mathrm{mL}$ on the graph paper and were expressed as $\mathrm{mIU} / \mathrm{mL}$. The sensitivity of assay was $5.5 \mathrm{mIU} / \mathrm{mL}$. The average linearity of assay was $104 \%$. The inter and intra-run precision had a co-efficient of variation of $6.3 \%$ and $5.5 \%$ respectively.

The data generated on various parameters was subjected to statistical analysis using FCRD (Factorial Completely Randomized Design) (Snedecor and Cochran, 1994). 


\section{RESULTS}

Plasma LH concentration in group of normal fertile cows was non-significantly increase from $1.8 \pm 0.20 \mathrm{mIU} / \mathrm{mL}$ at 8 hours to $1.87 \pm 0.22 \mathrm{mIU} / \mathrm{mL}$ at 10 hours after the onset of estrus. However, from 12 hours onwards it was fluctuated non-significantly up to 18 hours and reached at peak level $(4.62 \pm 0.52 \mathrm{mIU} / \mathrm{mL})$ at 20 hours after the onset of estrus. The significantly $(\mathrm{p}<0.05)$ elevated LH level in control group was maintained up to the 24 hours post estrus. The concentration measured at this time was greater than that measured at any other time during estrus indicated that $\mathrm{LH}$ reach definite peak at 20 to 22 hours post estrus (Table 1 and Fig. 1).
However, in case of LH RB group no such fluctuations in the LH concentration was recorded and the highest $(2.13 \pm 0.29 \mathrm{mIU} /$ $\mathrm{mL}$ ) level observed in this group was only at 16 hours post estrus. While during all other periods LH levels remained within the range of $1.22 \pm 0.26$ to $1.92 \pm 0.34 \mathrm{mIU} /$ $\mathrm{mL}$. Further, the concentration of $\mathrm{LH}$ was at par between LH CON and LH RB groups during 8 and 10 hours post estrus. However, 12 hrs. post estrus onwards the LH concentration was significantly $(\mathrm{p}<0.05)$ low in LH RB group as compared to LH CON group till 36 hours post estrus (Table 1 and Fig. 1).

Table 1. Plasma luteinizing hormone profiles in Kankrej cow during estrus

\begin{tabular}{|c|c|c|}
\hline \multirow[b]{2}{*}{$\begin{array}{l}\text { Time of collection (hrs.) } \\
\text { after onset of estrus }\end{array}$} & \multicolumn{2}{|r|}{ Groups } \\
\hline & $\begin{array}{c}\text { LH CON }(n=6) \\
(\text { Mean } \pm \text { SE })(\mathrm{mIU} / \mathrm{mL})\end{array}$ & $\begin{array}{c}\text { LH RB }(\mathrm{n}=6) \\
(\text { Mean } \pm \text { SE })(\mathrm{mIU} / \mathrm{mL})\end{array}$ \\
\hline 8 & $1.80 \pm 0.20^{a}$ & $1.67 \pm 0.35 \mathrm{ab}$ \\
\hline 10 & $1.87 \pm 0.22_{\mathrm{x}}^{\mathrm{a}}$ & $1.82 \pm 0.30_{\mathrm{x}}^{\mathrm{ab}}$ \\
\hline 12 & $2.80 \pm 0.49_{\mathrm{x}}^{\mathrm{bc}}$ & $1.73 \pm 0.29_{\mathrm{y}}^{\mathrm{ab}}$ \\
\hline 14 & $2.50 \pm 0.42_{\mathrm{x}}^{\mathrm{x}}{ }^{\mathrm{ab}}$ & $1.82 \pm 0.24_{\mathrm{y}}^{\mathrm{y}}$ \\
\hline 16 & $2.40 \pm 0.45_{\mathrm{x}}^{\mathrm{x}}$ & $2.13 \pm 0.299_{\mathrm{y}}^{\mathrm{b}}$ \\
\hline 18 & $2.78 \pm 0.56_{x^{x}}^{\mathrm{bc}}$ & $1.92 \pm 0.34_{\mathrm{y}}^{\mathrm{y}}$ \\
\hline 20 & $4.62 \pm 0.52 \mathrm{~g}$ & $1.30 \pm 0.19$ a \\
\hline 22 & $4.43 \pm 0.73^{\mathrm{fg}}$ & $1.27 \pm 0.39$ a \\
\hline 24 & $4.02 \pm 0.24_{\mathrm{x}}^{\mathrm{efg}}$ & $1.70 \pm 0.35_{\mathrm{y}}^{\mathrm{ab}}$ \\
\hline 26 & $3.75 \pm 0.27_{\mathrm{x}}^{\mathrm{def}}$ & $1.37 \pm 0.30_{\mathrm{y}}^{\mathrm{a}}$ \\
\hline 28 & $3.50 \pm 0.19^{\mathrm{cde}}$ & $1.40 \pm 0.12^{\mathrm{a}} \mathrm{a}$ \\
\hline 30 & $3.67 \pm 0.34^{\mathrm{x}} \mathrm{de}$ & $1.68 \pm 0.15^{\mathrm{y}} \mathrm{ab}$ \\
\hline 32 & $2.76 \pm 0.32_{\mathrm{x}}^{\mathrm{b}}$ & $1.43 \pm 0.14_{\mathrm{y}}^{\mathrm{y}}$ \\
\hline 34 & $3.11 \pm 0.70_{x}^{b c d}$ & $1.34 \pm 0.08_{\mathrm{y}}^{\mathrm{a}}$ \\
\hline 36 & $2.76 \pm 0.44_{x}{ }^{b}$ & $1.22 \pm 0.26_{\mathrm{y}}^{\mathrm{y}}$ \\
\hline
\end{tabular}

Means bearing different superscripts within a column (within the groups, viz. a, b...) and means bearing different subscripts within a row (between the groups, viz $x, y \ldots$ ) differ significantly $(\mathrm{p}<0.05)$ 


\section{Concentration of $\mathrm{LH}(\mathrm{mIU} / \mathrm{mL})$}

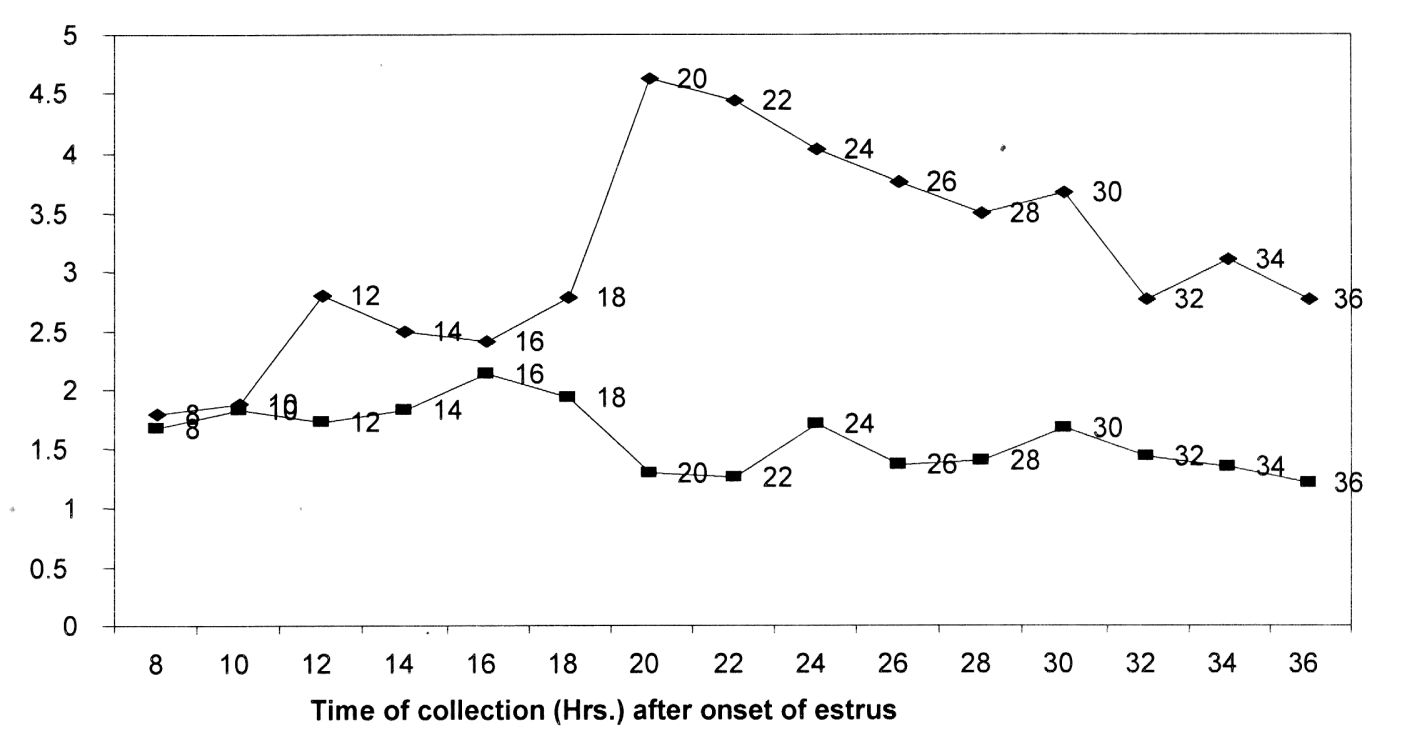

$$
\longrightarrow \text { LH CON } \longrightarrow-\text { LHRB }
$$

Fig. 1. Average value of leutinizing hormone $(\mathrm{mIU} / \mathrm{mL})$ in Kankrej cow during estrus

\section{DISCUSSION}

In the present study, the undeniably preovulatory LH surge was observed in normal Kankrej cows which persist about 6 hours whereas, it was only transitory in case of repeat breeding Kankrej cows as the LH concentrations observed in repeat breeding Kankrej cows was remain remarkably stable during the estrus.

Similar findings were observed by Hackett and Hafs (1969) who observed the LH surge varied from 8 hours before to 8 hours after the end of the standing heat. However, Swanson and Hafs (1971) observed the peak of LH 3 hours before the standing heat. Further, Henricks et al. (1970) observed peak LH levels at 3 to 6 hours after the onset of estrus in non-lactating cows. The peak of $\mathrm{LH}$ at the onset of estrus was lasted between 6 and 16 hrs. have been reported by many authors (Christensen et al., 1974; Kiddy and Odell, 1969; Schams and Karg, 1969; Snook et al., 1971; Sprague et al., 1971; Varian et al., 1968).

Starbuck et al. (2006) observed the time of elevation in plasma $\mathrm{LH}$ as $54.06 \pm 4.0$ hours following luteolysis. Roy and Prakash (2008) recorded the LH surge from 6 to 10 hours of induced estrus in Murrah buffalo heifers. Discrepancy in levels of $\mathrm{LH}$ reported by various authors may be due to 
the frequency and time of sampling. Schams and Karg (1969) opined that LH concentration above a baseline level last less than 6 hrs.

Scanning through the available literature revealed no such studies. However, from the above findings it can be postulated that the low levels of LH in repeat breeder Kankrej cows may be the cause for repeat breeding condition of the animals. Reeves (1987) opined that preovulatory surge of LH lasting for 6 to 12 hours are responsible for ovulation which is in response to the increase in circulatory concentrations of estrogen. Further, Niswender and Nett (1988) reported that principal hormone which stimulates progesterone production by the CL is LH. A lot of literature is available supporting the luteotrophic nature of LH (Wiltbank et al., 1961; Roberts,

\section{REFERENCES}

Arthur GH, Noakes DE and Pearson H, 1989. Veterinary Reproduction and obstetrics. ELBS, Sixth Edn., Bailiere Tindall, London

Ayad A, Sousa NM, Sulon J, Hornick JL and Watts J et al., 2007. Influence of progesterone concentrations on secretory functions of trophoblast and pituitary during the first trimester of pregnancy in dairy cattle. Theriogenology, 67: 1503-1511

Christensen DS, Hopwood ML and Wiltbank JN, 1974. Levels of hormones in the serum of cycling beef cows. J Anim Sci, 38: $577-583$
1986; Hafez, 1987; Arthur et al., 1989; Ayad et al., 2007).

The surge level of $\mathrm{LH}$ in normal breeder last for 6 hours, whereas no such surge level was recorded in repeat breeder Kankrej cows and which might be a reason for repeat breeding condition in animals.

Conflict of interest: Authors declare that there is no conflict of interest regarding the present research work.

\section{ACKNOWLEDGEMENT}

The authors are highly thankful to the Dean, College of Veterinary Science and A.H. for financial assistance and research facilities to conduct this experiment. The authors also thank Research Scientist, Livestock Research Station, SDAU for the availability of experimental animals.

Hackett AJ and Hafs HD, 1969. Pituitary and hypothalamic endocrine changes during the bovine estrous cycle. J Anim Sci, 28: 531

Hafez ESE, 1987. Reproduction in Farm Animals. $5^{\text {th }}$ Edn., Lea and Febiger, Washington, Philadelphia

Henricks DM, Dicky JF and Niswender GD, 1970. Serum luteinizing hormone and plasma progesterone levels during the estrus cycle and early pregnancy in cows. Biol Reprod, 2: 346-351

Kiddy A and Odell AD, 1969. Radioimmunoassay of blood $\mathrm{LH}$ at 
estrus and ovulation in cattle. J Anim Sci, 29: 152.

Niswender GD and Nett TM, 1988. The corpus luteum and its control. In: Knobil E, Neill J (Edns.), The Physiology of Reproduction. New York: Raven Press, pp 489-525

Reddy KRC, Reddy KCS and Reddy VCS, 2001. Efficacy of progesterone treatment in repeat breeding Ongole cattle. Indian Vet Med Jour, 25(2): 193

Reeves JJ, 1987. Endocrinology of reproduction. Cited in Reproduction in Farm Animals. $5^{\text {th }}$ Edn., Lea and Febiger, Washington, Philadelphia

Roberts SJ, 1986. Veterinary Obstetrics and Genital Diseases (Theriogenology). $3^{\text {nd }}$ Edn., Woodstock, Vermont, USA

Roy KS and Prakash BS, 2008. Plasma luteinizing hormone profiles during ovsynch treatment in Murrah buffalo heifers. Indian Vet J, 85: 678-679

Schams D and Karg H, 1969. Radioimmunologische LH-bestimmung in blutserum vom rind unter besonderer berucksichtigung des brunstzyklus. Acta Endocrinol, 61: 96-103

Sharma A, Singh M and Vasishta NK, 2006. Studies on the effect of gonadotrophins releasing hormone administration on conception rate following artificial insemination in cattle maintained under sub-temperate climate. Indian J Anim Reprod, 27(1): 66-68

Snedecor GW and Cochran KG, 1994. Statistical methods. $8^{\text {th }}$ Edn., Oxford and IBH publishing co., New Delhi, India

Snook RB, Saatman RR and Hansel W, 1971. Serum progesterone and luteinizing hormone levels during the bovine estrus cycle. Endocrinol, 88: 678

Sprague EA, Hopwood M L, Niswender GD and Wiltbank JN, 1971. Progesterone and luteinizing hormone levels in peripheral blood of cycling beef cows. J Anim Sci, 33: 99

Starbuck GR, Gutierrez CG, Peters AR and Mann GE, 2006. Timing of follicular phase events and the postovulatory progesterone rise following synchronisation of oestrus in cows. The Vet J, 172: 103-108

Swanson LV and Hafs HD, 1971. LH and prolactin in blood serum from estrus to ovulation in Holstein heifers. J Anim Sci, 33: 1038-1041

Varian NB, Henricks DM and Melampey RM, 1968. Luteinizing hormone activity in bovine plasma. Iowa state J Sci, 42: 319324

Wiltbank JN, Rothlisberger JA and Zimmerman DK, 1961. Effect of human chorionic gonadotropin on maintenance of the corpus luteum and embryonic survival in the cows. J Anim Sci, 20: 827 